\title{
РЕТРОСПЕКТИВАСВІТОВОÏ ЕКОНОМІЧНОЇДУМКИ
}

Удк $330.8: 016$

Оксана ШИМАНСЬКА

\section{ЕЛІНОР ОСТРОМ: ДОВЕДЕННЯ ЕФЕКТИВНОСТІ КОЛЕКТИВНОГО УПРАВЛІННЯ}

(Нобелівська премія з економіки 2009 р.

“за дослідження в галузі економічної організації”)

\begin{abstract}
Обірунтовано внесок Елінор Остром у розвиток теорії колективного управління власністю. З'ясовуються способи вирішення проблеми найоптимальнішого використання обмежених природних ресурсів задля забезпечення можливостей їх економічно релевантного збереження у довгостроковій перспективі. Відстоюється думка про те, що не лише держава може вирішувати проблеми ефективного використання ресурсів, призначених для спільного користування. Доведено можливість застосування колективних рішень у сфері управління ресурсами, за яких останні підтримуються в нормальному стані, залишаючись водночас в режимі загального користування. Розглянуто найавторитетніші моделі ("трагедія общин”, “дилема ув'язненого", “логіка колективної дії"), які найчастіше використовуються в якості інструментарію для дослідження випадків застосування конкретних заходів економічної політики у срері використання обмежених ресурсів загального користування, а такожяк концепції аналізу проблем індивідів, котрі прагнуть досягнення колективної вигоди. Наголошується увага на необхідності виваженого застосування вищезгаданих моделей у якості метасрор-замінників реальних засад економічної політики, оскільки обмеження, які для зручності аналізу пропонується сприймати в якості постійних, приймаються такими без будь-яких упереджень - як постійні емпіричні умови, які залишаються такими до моменту внесення коректив з боку органів державної влади. Наголошено на важливості розробки теорій людської організації, заснованих на реалістичній оцінці людських можливостей та обмежень, які виникають у випадку необхідності вирішувати безліч різних ситуацій у сфрері використання спільних благ. Акцентується увага на тому, що емпірично підтверджені теорії людської організації як найважливіший елемент науки про економічну політику здатні доповнювати рішення оцінками найбільш ймовірних наслідків застосування безлічі способів організації видів людської діяльності. Зроблено висновок, що експериментальні дослідження Е. Остром у сфері управління природними ресурсами можуть бути використані задля вирішення масштабного кола проблем, пов'язаних із виробництвом суспільних благ.
\end{abstract}

(c) Оксана Шиманська, 2017. 


\section{О. Шиманська}

Елінор Остром: доведення ефективності ...

Ключові слова: ресурси спільного користування, "трагедія общин”, “дилема ув'язненого”, “логіка колективної дії”, теоретико-ігрові моделі, моделі-метафори, кооперативна гра, некооперативна гра, державні інститути, права приватної власності, колективне управління власністю.

JEL: A 11, B 31, C 71, C 72, D 74

Постановка проблеми. Проблема ефективного управління ресурсами, насамперед природними, які спільно використовуються великою кількістю індивідів, є однією із ключових проблем не лише сучасної економічної науки, а й фахівців, які займаються розробкою засад економічної політики. Задля їі вирішення, зазвичай, пропонується або державне регулювання, або приватизація таких ресурсів. Однак з огляду на те, що ані держава, ані ринок не продемонстрували однозначно успішних результатів у цій сфері, актуальним вбачається пошук альтернативних способів вирішення проблеми.

Аналіз останніх досліджень і публікацій. У працях У. Офульсса [6], Р. Хейлбронера [7], Д. Еренфельда [8], І. Каррузера [9], Р. Стоунера [9], К. Кларка [13] відстоюється думка про те, що лише держава може ефективно вирішувати проблеми використання ресурсів, призначених для спільного користування. Інші дослідники, зокрема Г. Демсетц [10], О. Джонсон [11], В. Уелч [12], доволі впевнено рекомендують вводити приватну власність у всіх випадках наявності ресурсу спільного володіння. Теоретичні ж дослідження Е. Остром, підкріплені масивом емпіричних даних, підтверджують можливість застосування колективних рішень управління ресурсами, за яких останні підтримуються в нормальному стані, залишаючись водночас в режимі загального використання.

Постановка мети і завдань дослідження. Метою статті $є$ дослідження потенціалу вирішення проблем у сфері колективного використання обмежених ресурсів, запропонованих Е. Остром, які не піддаються ні приватновласницьким, ні урядовим підходам.

Виклад основного матеріалу. Елінор Остром у своїх дослідженнях заперечила думку про неефективність колективного управління власністю. Досліджуючи численні приклади суспільного регулювання рибальства, використання пасовищ, лісів, озер і підземних вод, Е. Остром дійшла висновку, що в багатьох випадках результати колективних дій $€$ значно ефрективнішими, аніж прогнози стандартних моделей.

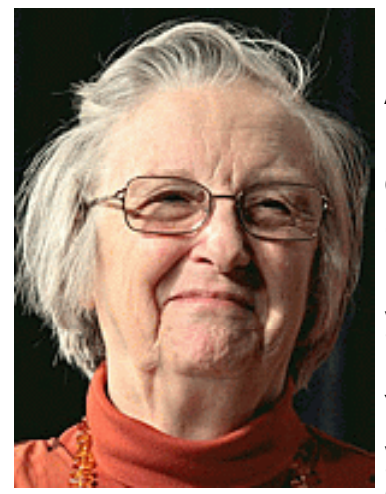

Американський політолог і економіст Елінор Остром (в дівоцтві Ейвен) народилася 7 серпня 1933 р. в Лос-Анджелесі в родині Адріана і Лії Ейвенів.

У 1951 р. закінчила Beverly High School. Невдовзі здобула ступені бакалавра політичних наук (1954р.), магістра мистецтв (1962 р.), доктора фрілософії (1965 р.) Каліфрорнійського університету. Під час виконання останньої випускової роботи Е. Остром брала участь у дослідницькій групі з вивчення водного господарства Південної Каліфорнії. Професійну діяльність розпочала в Університеті Індіани на посаді викладача “Основ американського уряду". Згодом працювала в комітеті з дослідження водних басейнів, створеному Національною дослідницькою радою. У 1974

р. Е. Остром отримала посаду професора в Університеті Індіани. 31982 по 1984 рр. була Президентом організації “Громадський вибір”. 31984 по 1985 рр. Е. Остром - Президент 
Середньозахідної асоціації політичних наук. У 1990 р. опублікувала свою головну книгу “Управління спільним: еволюція інститутів колективних дій”. З 1996 по 1997 рр. Е. Остром очолювала Американську асоціацію політичних наук.

Визнання Елінор Остром принесли дослідження у сфері корпоративного управління суспільною власністю. У 2009 р. Елінор Остром спільно з Олівером Вільямсоном була удостоєна Нобелівської премії з економіки “за дослідження в галузі економічної організації”. Таким чином, Елінор стала першою жінкою, яка отримала Нобелівську премію з економіки. Відзначена Преміями Сейдмана (1997), Йохана Скітте (1999), Джеймса Медісона (2005), Джонатана Тиша (2009). 31991 р. Е. Остром є членом Американської академії мистецтв і наук. 32001 р. - член Національної академії наук США. У 2010 р. включена американським журналом “Utne Reader"в число "25 людей, які змінюють світ” [1].

У своїй праці “Управління спільним: еволюція інститутів колективних дій” Е. Остром зосереджує увагу на головній для розуміння проблемі: як саме у найкращий спосіб обмежити використання природних ресурсів, щоб у довгостроковій перспективі забезпечити можливість їх економічно релевантного збереження [2, с. 21]. Вчені, які досліджували феномен "трагедії общин" (предтеча теорії Е. Остром), насамперед рекомендують задля запобігання вичерпуванню ресурсів встановити державний контроль за використанням більшості їх видів. Інша група вчених вважають приватизацію єдиним ефективним способом вирішення усіх проблем. Однак Е. Остром наголошує, що наразі у світі склалась ситуація, за якої ані держава, ані ринок не демонструють жодних значних успіхів у справі надання індивідам можливостей для досягнення стійкого економічного розвитку на підґрунті продуктивного використання систем природних ресурсів. Багато спільнот уже задіяли інститути - не схожі ні на державу, ні на ринок, - які дозволяють достатньо успішно керувати деякими ресурсними системами в довгостроковому періоді [2, с. 22].

Е. Остром описує три найавторитетніших моделі, які найчастіше використовуються в якості інструментарію для дослідження випадків застосування конкретних заходів економічної політики у сфері використання багатьох видів природних ресурсів, успішних і невдалих спроб контролю і регулювання у цій сфрері, а також для розробки інтелектуального інструментарію, який би дозволив краще зрозуміти можливості і обмеження інститутів саморегулювання у випадку використання багатьох видів природних ресурсів.

Перша модель у науковій літературі отримала вищенаведену назву “Трагедія общин”. Ця дефініція почала широко використовуватися після опублікування в журналі "Science" статті Г. Хардіна “Tragedy of the Commons" (1968р.). "Трагедія общин” відображає процес деградації навколишнього середовища, який слід очікувати в ситуаціях, за яких велика кількість індивідів спільно використовує певний обмежений ресурс [2, с. 23]. Логічна структура моделі Г. Хардіна базується на гіпотетичному прикладі пасовища, "відкритого для всіх". Вчений аналізував особливості такої ситуації з точки зору раціонального власника стада. Кожен власник отримує безпосередню вигоду від володіння тваринами, які йому належать, і несе відкладені витрати внаслідок того, що спільне пасовище поступово стає непридатним через витоптування як його власними тваринами, так і тваринами, які належать іншим власникам. Кожен власник стада вмотивований збільшити поголів'я, випасати на цьому пасовищі додаткову кількість тварин, оскільки отримує безпосередню вигоду, пов'язану з володінням ними, і несе лише частину витрат, які пов'язані з “потравою” випасу (зниженням якості пасовища). Г. Хардін дійшов висновку: "У цьому й криється 
трагедія. Кожен замкнутий в межах системи, яка спонукає його безмежно збільшувати своє стадо, -у просторі, який є обмеженим. Кінцевим пунктом, до якого поспішають усі, $€$ катастрофа, - кожен переслідує власний інтерес у суспільстві, яке вірить в свободу общин" [3, р. 1244].

Дослідження, які проводяться в межах економіки ресурсів, зазвичай, підтверджують факт того, що там, де лише обмежена кількість користувачів має доступ до спільних ресурсів, сукупний обсяг їх використання буде перевищувати оптимальний рівень відбору [2, с. 24]. Е. Остром констатує, що більша частина світу залежить від ресурсів, які потенційно схильні до “трагедії общин” [2, с. 25].

Друга модель “Дилема ув'язненого” презентує формалізовану (у вигляді гри) модель Г. Хардіна. Е. Остром припускає, що учасниками гри є власники стад, які спільно використовують одне пасовище. У випадку останнього існує верхня межа кількості тварин (L), яких можна випасати кожний сезон, отримуючи до його закінчення якнайкраще відгодоване поголів'я. Для гри за участю двох осіб кооперативною стратегією може вважатися така поведінка, за якої кількість тварин, яку випасає кожен власник на спільному лузі, дорівнює L/2. Стратегія збитку ("потрави" випасу) для кожного власника стада полягає в тому, щоб випасати на пасовищі таку кількість тварин, за якої (за його передбаченнями) їх реалізація наприкінці сезону забезпечить йому максимальний прибуток (за обсягу заданих витрат, які він несе в приватному порядку); ймовірно ця кількість перевищуватиме L/2. Якщо обидва власники обмежать кількість тварин, яку кожен з них випасає на спільному лузі, величиною L/2, то вони отримають 10 одиниць прибутку. Якщо ж вони обидва оберуть стратегію збитку, то жоден з них взагалі не отримає ніякого прибутку [2, c. 26]. У випадку обмеження одним з них кількості тварин величиною L/2, з одночасним випасом іншим стількох тварин, скількох він забажає, такий "виснажувач" отримає 11 одиниць прибутку, а власник, який обмежив випас свого поголів'я, отримає збиток, або прибуток у розмірі -1. Якщо кожен здійснюватиме вибір незалежно один від одного і не матиме можливості укласти з іншою стороною зобов'язуючий контракт, то вони обидва оберуть стратегію домінування, яка призведе до збитків (“потрави” пасовища). Якщо кожен здійснить таку дію, то і один, i інший отримають нульовий прибуток. Цю гру Е. Остром назвала “грою стада за Хардіном" [2, с. 27]. За своєю структурою вона співпадає з грою “Дилема ув'язненого”', яка відображає концепцію некооперативної гри, у якій всі гравці володіють повною інформацією. У некооперативних іграх комунікація між гравцями

\begin{abstract}
${ }_{1}$ Якщо обидва затриманих зізнаються у злочині, за яким відкрито провадження, їх ув'язнять, однак прокурор проситиме суд визначити менший термін покарання, аніж максимально можливий. Якщо ж один із затриманих зізнається, а інший не визнає своєї провини, то той, котрий зізнається, за викривання злочинця отримає м'який вирок, тоді як той, котрий не зізнається, отримає термін покарання у вигляді пожиттєвого утримання. Стратегічне завдання в одиницях років відбування терміну покарання може бути представлене наступним чином [2, с. 26]:
\end{abstract}

\begin{tabular}{|c|c|c|}
\hline & \multicolumn{2}{|c|}{ Ув'язнений 2 } \\
\hline Ув'язнений 1 & Визнає провину & Не визнає провини \\
\hline Визнає провину & 1 рік кожному & $\begin{array}{c}10 \text { років ув'язненому } 1 \\
3 \text { місяці ув'язненому 2 }\end{array}$ \\
\hline Не визнає провини & $\begin{array}{c}3 \text { місяці ув'язненому 1, } \\
10 \text { років ув'язненому 2 }\end{array}$ & 8 років кожному \\
\hline
\end{tabular}


або неможлива, або не релевантна (лише за умови, якщо вона не є явним елементом гри). Якщо комунікація можлива, усні домовленості між гравцями вважаються такими, що не мають обов'язкового характеру за умови, якщо можливість обов'язкової домовленості безпосередньо не вмонтована у структуру гри. “Повна інформація" означає, що всі гравці обізнані стосовно повної структури дерева гри і платежів, які пов'язані з кожним результатом гри. Гравці або обізнані, або не обізнані про черговий хід іншої сторони, в залежності від того чи ведеться спостереження за їх кроками, чи ні [2, с. 27].

У грі “Дилема ув'язненого” кожен гравець володіє домінантною стратегією - завжди знаходиться у виграшній позиції, обираючи ії, - зважується вдаватись до "потрави" пасовища незалежно від вибору іншого гравця. У випадку, коли обидва гравці обирають свої домінантні стратегії за даних передбачень, вони породжують рівновагу, яка буде третьою в низці найкращих результатів для них обох (тобто краща, ніж друга, яка, водночас, гірша, ніж перша). Незважаючи на стратегію, яка обрана іншою стороною, жоден з гравців не має стимулів змінювати це становище. Рівновага, яка зумовлена тим, що кожна сторона обирає власну "найкращу" індивідуальну стратегію, не є, однак, оптимальною за Парето. Ситуація вважається оптимальною за Парето, якщо не існує жодного кінцевого розподілу, який би був чітко найбажанішим хоча б для одного учасника i, при цьому, - найменшою мірою таким же бажаним для інших. У грі “Дилема ув'язненого” для двох осіб обидва гравці надають перевагу результату “співпрацювати; співпрацювати" варіанту "”потрава"; "потрава"”. Таким чином, досягнення рівноваги є гіршим від оптимального за Парето. На думку Е. Остром, висновком з цієї гри є парадокс: раціональні стратегії на індивідуальному рівні призводять до результату, який є ірраціональним 3 точки зору колективу [2, с. 28].

Третя модель “Логіка колективної дії” описана Е. Остром на основі наукового доробку відомого вченого М. Олсона, відображеного у його праці “Логіка колективної дії” [4]. Ідея стосовно того, що групи діють з метою забезпечення своїх колективних інтересів, логічно доводиться на підставі доволі поширеного припущення про раціональну поведінку, яка спрямована на забезпечення власного інтересу. Тобто, якщо члени будь-якої групи об'єднані спільними інтересами або однією метою і якщо усі вони отримають вигоду у випадку досягнення останньої, то вважається, що індивіди, які складають цю групу, будуть (якщо вони раціональні і переслідують власний інтерес) діяти у напрямку досягнення поставленої спільної мети [4, р. 1]. М. Олсон заперечує припущення, згідно з яким можливість отримання групового виграшу вбачається достатньою причиною виникнення колективної дії, спрямованої на досягнення спільної мети. Вчений констатує, що "якщо кількість членів групи не є гранично малою і якщо немає втручання ззовні / або якийсь механізм не чинить впливу на індивідів стосовно дій в їх спільних інтересах, то раціональні індивіди, переслідуючи свій власний інтерес, не діятимуть задля досягнення спільних або групових інтересів" [4, р. 2]. Аргументація М. Олсона здебільшого ґрунтується на припущенні, згідно з яким той, хто не може бути виключеним із кагорти отримувачів вигоди від колективного блага після його створення, має мало стимулів для добровільного включення у його виробництво [2, с. 30]. При цьому вчений оперує визначенням "група середніх розмірів", яке відображає залежність не від кількості діючих осіб, а від того наскільки значимою є дія кожної окремої особи для досягнення кінцевих результатів групою в цілому. 
“Трагедія общин”, “дилема ув'язненого” та “логіка колективної дії”, які реалізовані у вигляді моделей, репрезентують тісно взаємопов'язані концепції як доволі зручний інструмент для аналізу багатьох проблем індивідів, котрі прагнуть досягнення колективної вигоди [2, с. 30]. Е. Остром наголошує, що кожна з моделей сфокусована на проблемі "халявщика"1. Якщо окремий індивід не може бути вилученим із процесу отримання вигод, створених іншими, кожен вмотивований не здійснювати внеску в спільні зусилля, надаючи перевагу використанню задарма результатів зусиль інших. Якщо поведінку "халявщика" оберуть усі учасники, то колективне благо не буде створене. Тобто в процесі прийняття рішення всі можуть спокуситися отримати колективне благо задарма i, таким чином, все може звестися до отримання результату, якого не бажав ніхто. 3 іншого боку, якщо свій внесок забезпечуватимуть лише деякі учасники, а інші “халявитимуть”, це відобразиться в такому рівні отримання колективних вигод, який буде нижчим від оптимального (субоптимальний результат) [2, с. 31]. Відтак ці моделі, на думку Е. Остром, вкрай корисні для обґрунтування того, в який спосіб достеменно раціональні індивіди схильні за певних обставин породжувати такий результат, який $€$ не раціональним, оцінюючи його з точки зору усіх осіб, залучених у процес.

Однак Е. Остром застерігає про небезпеку застосування вищезгаданих моделей -у випадках, коли останні використовуються в якості не більше, аніж метафор-замінників реальних засад економічної політики, оскільки обмеження, які для зручності аналізу пропонується сприймати в якості постійних, приймаються постійними на віру (так, начебто вони є постійними емпіричними умовами і залишалися б такими до того часу, допоки їх не змінила б влада). "Ув'язнені" з відомої “дилеми" не можуть змінити обмеження, які накладені на них з боку прокурора, - адже вони відбувають покарання у в'язниці. Е. Остром наголошує, що не для усіх користувачів природних ресурсів характерна та ж міра нездатності змінити свої обмеження. Допоки індивіди трактуються як “ув'язнені", рекомендації у сфрері економічної або соціальної політики виглядатимуть не більше, аніж метафори [2, с. 32]. Подібність між індивідами, які спільно використовують ресурси навколишнього природного середовища та індивідами, які спільно породжують субоптимальний розв'язок моделі, використовується для тлумачення ідеї, згідно з якою подібність проявляється і у всіх інших відносинах. Визначаючи умови експлуатації загального ресурсу “трагедією общин”, “проблемою колективної дії”, “дилемою ув’язненого”, "ресурсом загального доступу" або навіть "ресурсами, що знаходяться в колективній власності”, дослідник часто демонструє бажання змалювати портрет безпорадних індивідів, втягнутих у невблаганний процес руйнування їх власних ресурсів [2, с. 34]. Доказом цього слугує один із висновків Е. Остром: ефективне регулювання рибальства можливе, начебто, лише у випадку визнання того фракту, що "якщо все залишити на розсуд самих рибалок, вони неминуче будуть виснажувати промислові запаси риби”, i

\footnotetext{
1 “Халявщик” - сленговий варіант перекладу слова free-rider (“безбілетник, безбілетний пасажир"), який точніше визначає суть поведінки, аніж англійський термін, оскільки термін "безбілетник" може ввести в оману в силу сконцентрованості на певному специфрічному способі дармового отримання колективної вигоди (до того ж в буденному сенсі “безбілетник" не отримує колективної вигоди, оскільки проїзд в громадському транспорті не можна вважати процесом створення колективного блага) [2, с. 30].
} 
що "менеджери повинні керувати всіма аспектами діяльності рибалок-задля запобігання катастрофи" [2, с. 34].

Е. Остром зазначає, що державні чиновники, апелюючи до суспільної свідомості, час від часу використовують спрощені версії вищезгаданих моделей. При цьому процеси в моделях утотожнюються з процесами реальної дійсності. Так, зокрема, канадський міністр у справах рибальства та океанів Р. Леблан у своєму виступі, присвяченому 50річчю United Marine Fishermen 19 березня 1980 р., наголосив: “Якщо допустити реалізацію індивідуального економічного інтересу в рибальстві, тобто якщо кожен буде ловити стільки риби, скільки він захоче, черпаючи з ресурсу, який не належить ніякій особі, справа закінчиться розоренням як сусідів, так і самих себе. В умовах свободи рибальства хороші часи стають причиною поганих, - вони заохочують все більше суден, які виловлюють все менше риби, що позначається все меншими доходами, які розподіляються між усе більшою кількістю людей" [5]. Під цим криється те, що реальне канадське рибальство повністю відповідає модельному визначенню, яке, однак, на думку Е. Остром, вбачається емпірично некоректним [2, с. 34]. Однак той фракт, що багато ресурсів дійсно схожі на ті, які описуються вищезгаданими трьома моделями, породжує апріорне припущення про перебування індивідів у ситуації безвихідної пастки. Цілком справедливо, що й рекомендації у сорері економічної політики, які ґрунтуються на цих позиціях, також несуть у собі відбиток безвихідності. В якості підтвердження цієї думки, Е. Остром наводить цитату з праці У. Офульса: “Внаслідок дії ефектів “трагедії общин” проблеми навколишнього середовища не можуть бути вирішені за допомогою співпраці... тут переважають міркування на користь масштабного силового втручання” [6]. У свою чергу, Г. Хардін також стверджує, що єдиними альтернативами "дилеми общин" $є$, з одного боку, "система приватного підприємництва", а, з іншого, - те, що називається "соціалізмом" [2, с. 35]. Гіпотеза, згідно з якою задля уникнення "трагедії общин” необхідним є втручання якогось зовнішнього по відношенню до людей Левіафана, призводить до рекомендацій стосовно контролю за більшістю систем природних ресурсів з боку центрального уряду. Хейлбронер вважає, що для того, щоб впоратися з проблемами навколишнього середовища, необхідна "залізна" і, навіть, мілітаристська держава [7]. Менш різка точка зору була висловлена Еренфельдом, який припустив, що оскільки "від приватних інтересів не можна очікувати захисту об'єктів загального володіння (public domain)”, то “тут необхідно зовнішнє регулювання з боку державних агентств, урядів чи міжнародних організацій” [8, р. 322]. У своїх дослідженнях проблем водокористування в країнах, що розвиваються, Каррузер і Стоунер констатують, що внаслідок відсутності державного контролю матимуть місце "надмірний випас і ерозія ґрунтів на общинних пасовищах, виснажливий вилов риби - за підвищених середніх витрат". Вчені роблять висновок, згідно з яким "ресурси, які знаходяться у спільній власності, вимагають державного контролю, якщо їх експлуатація може бути економічно ефективною" [9, р. 29].

Інші дослідники сфрер економічної політики, які ґрунтувались на вищезгаданих моделях, доволі впевнено рекомендують вводити приватну власність у всіх випадках, коли наявним $€$ ресурс спільного володіння [10], [11], [12]. Ті, хто рекомендує перехід до приватної власності, на думку Е. Остром, пропонують розділити навпіл спільний ресурс (пасовище), віддаючи одну половину одному, а іншу - іншому власнику. У цьому випадку кожен власник вестиме гру не проти іншого власника на великій ділянці, а проти природи і на 
меншій ділянці. За нових умов кожен власник поголів'я тварин змушений буде інвестувати кошти (у встановлення огорожі, ії ремонт, забезпечення охорони території), розмір яких визначатиметься тим, як у первісному вигляді відбудеться розподіл спільного ресурсу (пасовища) [2, с. 41]. Е. Остром наводить гіпотетичний приклад, згідно з яким кожен власник стада, намагаючись отримати власну вигоду, обирає кількість тварин (X/2), випас яких здійснює на своїй частині пасовища. При цьому припускається, що випас характеризується повною однорідністю (у розумінні доступності корму), яка не змінюється з плином часу. Якщо кількість опадів над лугом нестійка, то якогось року на одній його частині може прорости якісна трава, в той час як кількість трави на іншій частині пасовища може не забезпечити поживу для X/2 поголів'я тварин. Наступного року опади можуть бути іншими. У будь-який заданий рік один із власників стада може не отримати прибутку, в той час як прибуток іншого може бути доволі значним. Якщо ділянки з хорошою врожайністю кормових трав з року в рік суттєво змінюються, то поділ спільного ресурсу на частини може призвести до зменшення доходів обох власників і “потрави” випасу на тих ділянках, кількість корму на яких тимчасово є недостатньою. Відтак власник, який у певному році отримав надлишок фуражу, може продати його іншому власнику. Інша можливість полягає в тому, що обидва власники можуть реалізувати деяку страхову суму задля зменшення ризиків, які пов'язані з невизначеністю параметрів навколишнього середовища. Однак початкові витрати на створення нового ринку або організацію нової системи страхування можуть бути доволі значними і зовсім не знадобляться у випадку, якщо власники продовжуватимуть розділяти кормову базу і ризик, спільно володіючи значно масштабнішим пасовищем [2, с. 42].

На думку Е. Остром стосовно деяких ресурсів спільного користування, інколи доволі складно зрозуміти, що саме мають на увазі аналітики, котрі вказують на необхідність введення права приватної власності [2, с. 42]. Вочевидь, якщо йдеться про землю, вони мають на увазі іï розподіл на окремі наділи (parcels) і встановлення прав утримувати, використовувати та передавати (rights to hold, use, and transfer) їх за бажанням окремих власників (припускаючи, що виконуються всі звичні положення права і вимоги законодавства у випадках використання і передачі землі). Однак не зовсім зрозуміло, на думку Е. Остром, що означає встановлення прав власності у випадку нестаціонарних ресурсів, таких, як водні або рибні. Зокрема, К. Кларк наголошує, що "трагедії общин" особливо важко протидіяти, якщо йдеться про ресурси морської риболовлі, де встановлення індивідуальних прав власності є практично неможливим" [13, р. 117]. Тобто стосовно таких "рухливих" ресурсів може забезпечуватись певне розмаїтяя прав - шляхом встановлення індивідуальних прав на використання певних видів обладнання, прав на використання ресурсів у визначений час або в певних місцях, або ж прав на вилучення певної кількості одиниць даного ресурсу (у випадку встановлення їх місця знаходження). Але навіть якщо такі специфічні права можна буде уніфікувати, квантифікувати і зробити об'єктом продажу, власне ресурсна система, на думку Е. Остром, найімовірніше, залишиться спільною, а не перебуватиме в індивідуальній власності [2, с. 43].

Аналітики, які зіштовхуються з емпіричною ситуацією, яка за логічною структурою співпадає з “дилемою общин”, часто вбачають вирішення проблеми у введенні ззовні сторонньої діючої особи (actor). Одна група прихильників цієї ідеї вважає, що на центральний орган має бути покладена постійна відповідальність задля забезпечення 
можливості приймати одиничні рішення стосовно конкретного ресурсу. Інші вважають, що центральний орган повинен наділяти правами власності на ресурс і згодом дозволяти індивідам переслідувати їх власні інтереси в межах чітко структурованої системи прав власності. Прихильники як централізації, такі приватизації переконані, що інституціональні зміни повинні з'явитись звідкись ззовні і нав'язуватись тим індивідам, яких вони стосуються. Незважаючи на те, що одні й інші переконані в необхідності та можливості участі держави у зміні інститутів з метою підвищення їх ефективності, інституційні зміни, які ними пропонуються, навряд чи можуть бути доволі масштабними [2, с. 44]. На думку Е. Остром, обидві ці позиції є вкрай хиткими. Науковець наполягає на необхідності розуміння існування множини рішень, які здатні вирішити безліч різних проблем. Хибним, на ії думку, є припущення про можливість швидкого знаходження оптимального інституційного рішення, яке може бути кимось спроектоване без будь-яких затрат і запроваджене під дією зовнішніх (відповідно до ситуації) сил. "Підбір правильного інституту" - це складний і конфліктний процес, який водночас вимагає значних затрат часу та надійної і релевантної інформації про змінні часу й місця, а також наявності широкого набору правил, які повинні бути культурно прийнятними [2, с. 44]. Інститути рідко $є$ виключно державними або виключно приватними, "ринком" або “державою". Багато успішних інститутів, які мають відношення до спільних ресурсів, відображають своєрідні суміші "начебто приватних" і “начебто державних", які не вдається класифікувати 3 використанням стерильних дихотомій [2, с. 45]. Конкурентний ринок як мікрокосм приватних інститутів, сам по собі є колективним благом. За його наявності індивіди можуть вільно входити і виходити з нього, незалежно від того чи несуть вони витрати з представлення ринку і підтримання його в дієвому стані, чи ні. Жоден ринок не зміг би існувати за відсутності підтримуючих його колективних інститутів. В реальній дійсності колективні та приватні інститути швидше змішані та взаємозалежні, аніж перебувають в ізольованих світах [2, с. 46].

У своїй праці Е. Остром здійснює пошук інституційних варіантів вирішення “дилеми общин”, базуючись на грі, за умовами якої власники спільного ресурсу самостійно формують обов'язковий контракт, підписуючи зобов'язання стосовно дотримання стратегії співробітництва. Задля включення цієї умови в загальну схему некооперативної гри остання вимагає доповнення додатковими опціями. В теорії некооперативних ігор обов'язковий контракт визначається як контракт, виконання якого забезпечується спонукальними діями когось ззовні, подібно до того, як невідворотність штрафнних санкцій забезпечується центральним органом [2, с. 46]. У випадку вирішення "дилеми общин" найпростіший спосіб представлення гри полягає в тому, щоб додати до платежів один параметр і ввести одну додаткову стратегію у множину стратегій власників ресурсу (поголів'я тварин). Параметром $€$ величина затрат на примусове виконання контракту (величина е). За цих умов перед тим, як вивести тварин на пасовище, їх власники зобов'язані вдатись до перемовин, в ході яких обговорюватимуться можливі стратегії розподілу “потужності" випасу, а також витрати на забезпечення виконання власних домовленостей. Однак контракти не містять примусових заходів за умови, якщо власники тварин не підтримують його одностайно. Будь-яка пропозиція одного з власників, яка не передбачає рівності часток “потужності" випасу і розподілу затрат на примусове виконання контракту, блокується за допомогою вето іншої сторони перемовин. Відповідно єдина 
досяжна угода (як і точка рівноваги, яка є наслідком цієї гри) полягає в тому, що обидва власники тварин порівну ділять стійкий продуктивний потенціал пасовища та витрати, пов'язані з примусом до виконання угоди, - якщо ці витрати у розрахунку на кожного власника менші від 10 [2, с. 47].

Окрім цього, в такій грі учасники завжди мають можливість вдатися до найгіршого варіанту розв'язку (“потрава”). Вони не залежать від точності інформації, отриманої віддаленим від місця подій державним чиновником, який оцінює їх стратегії [2, с. 47]. Якщо один гравець запропонує контракт, ґрунтуючись на неточній або неповній інформації, інший продемонструє свою незгоду. Учасники перемовин напрацюють свій власний контракт і закличуть до виконання того, хто здійснює силовий примус лише в тому випадку, якщо обидва на це погодяться. Якщо ця інстанція встановить за свої послуги надто велику плату (будь-яку суму $\geq P j(C, C)-P j(D, D) i=1,2)$, то на укладання такого контракту не погодиться жоден гравець. Такий результат гри не претендує на єдиновірний розв'язок “дилеми общин”. Однак цей спосіб майже повністю ігнорується як в літературі, присвяченій практичним аспектам розв'язку проблеми (policy-analysis literature), так і в літературі, присвяченій більш формальним питанням теорії ігор. Дослідження цього факту породжує багато питань. Насамперед, чи матиме можливість власник ресурсу найняти особу, котра забезпечить примусове виконання угоди? Насправді ця опція не є відірваною від реальності. Зокрема, в бізнесі багато довгострокових угод відображають “дилему ув'язненого” - в цій сфері прийнято вірити не в обіцянки бездоганного виконання контрактів у майбутньому, а, радше, довіряти контрактам, які передбачають примусовість виконання, особливо у випадках, коли ділові стосунки між сторонами встановлюються вперше. Причому розповсюдженою практикою зниження витрат, пов'язаних з примусом до виконання контракту, є використання в якості механізму забезпечення такого примусу приватного арбітра, а не цивільного суду [2, с. 48]. У цьому контексті Е. Остром наводить приклад роботи професійних спортивних ліг, які зіштовхуються з подібними проблемами, причому в умовах, коли кількість ресурсів становить N. Під час спортивного матчу за участю гравців професійної ліги завжди виникає спокуса порушення правил. Окрім цього, в грі інколи трапляється непередбачуване, зокрема, правила порушуються випадково, в тому числі й тими, хто не намагався їх порушувати. Зазвичай, професійні ліги з метою примушування до дотримання правил використовують послуги приватних арбітрів. Відтак арбітри, суди та інші договірні інститути примусу і вирішення суперечок відкривають для індивідів можливості виробляти довгострокові домовленості, які не були б задіяні за інших обставин [2, с. 49]. У цьому контексті важливо розуміти, що існують можливості вибору з-поміж кількох арбітрів, які пропонують послуги з примусу до виконання контракту, встановлюючи різні ставки винагороди на стадії перемовин. Рівновага, яка визначається платіжною матрицею, зміщуватиметься на користь того арбітра, який спонукатиме до виконання контракту за мінімальної величини е [2, с. 50]. Необхідність у зовнішніх спостерігачах і особах, які примушують до виконання контрактів, особливо гостро відчувається в тих випадках, коли те, до чого необхідно змусити, відображає рішення зовнішнього агентства, дії якого позначаться серйозними витратами для учасників [2, с. 51].

Ще одна проблема, на якій наголошує Е. Остром, пов'язана з тим, що аналітики та офіційні особи можуть плутати ігри, в яких примус організований на базі взаємних 
домовленостей, з іграми, в яких угоди стосовно організації співробітництва і примусу відсутні. Такі ситуації можуть сприйматися як неформальні, враховуючи той факт, що вони, найімовірніше, не мають санкції закону. Таке трактування, водночас, спирається на фрундаментальні припущення стосовно природи держави, яка вважається зовнішньою владою, що керує суспільством [2, с. 52]. Користувачі спільних ресурсів розробили широкий спектр найрізноманітніших угод, примус до виконання яких забезпечується за допомогою різноманітних механізмів. Деякі з них ґрунтуються на діяльності зовнішніх державних агентств, інші передбачають участь членів спільнот користувачів, які здійснюють функції спостерігачів та осіб, які забезпечують примус до виконання угод. Деякі механізми передбачають, що користувачі виконують роль спостерігачів за власними діями. В тих випадках, коли механізми примусу забезпечуються не зовнішніми державними агентствами, ряд аналітиків наполягає на відсутності примусу взагалі. Відтак структура інституціональних домовленостей, яка спостерігається в реальній дійсності, на думку Е. Остром, відображає вкрай складну систему, на противагу спрощеним теоретико-ігровим моделям [2, с. 52]. У випадку володіння спільним ресурсом учасники групи, яким він належить, можуть інколи не мати можливості комунікувати один з одним, або ж не мати шансів напрацювати довіру один до одного і виробити розуміння того, що їм доведеться розділити спільне майбутнє. У інших випадках ті індивіди, які наділені владою і отримують вигоди від статус-кво, можуть блокувати спроби змінити правила гри, до яких вдаються індивіди, наділені меншою владою. Задля вирішення ситуації, в якій панує спотворена логіка, такі групи можуть потребувати певних фоорм зовнішнього сприяння [2, с. 55].

Відмінності між тими, хто не в змозі знайти вихід з “дилеми общин”, і тими, хто зможе це зробити, можуть також зумовлюватися дією зовнішніх чинників. Деякі учасники не володіють достатньою мірою автономії задля зміни власних інституціональних структур, - влада ззовні, яка є байдужою або навіть лояльною до спотворень, згенерованих наявною системою відносин (зазвичай внаслідок отримання певних власних вигод), перешкоджає зусиллям таких учасників змінити систему. Цілком можливо, що за межами діючих груп відбуваються різкі зміни, які обмежують членів групи в часі задля пристосування власних внутрішніх інституціональних структур, уникнувши при цьому субоптимальних наслідків. Деякі групи відчувають негативний вплив спотвореної системи стимулів, яка склалася в результаті вжиття заходів з боку централізованої влади [2, с. 58].

Висновки. Е. Остром, таким чином, констатує, що виклики для вчених, які спеціалізуються на аналізі заходів економічної політики, полягають у розробці теорій людської організації, заснованих на реалістичній оцінці людських можливостей та обмежень, які виникають у випадку необхідності вирішувати безліч різних ситуацій, схожих на "трагедії общин” [2, с. 62]. Емпірично підтверджені теорії людської організації, як найважливіший елемент науки про економічну політику, зможуть доповнювати рішення оцінками найбільш ймовірних наслідків застосування безлічі способів організації видів людської діяльності. Дослідження Е. Остром вкрай корисні для тих, хто переконаний, що у вільному суспільстві не вся власність повинна бути приватною. Незважаючи на те, що Е. Остром провела масштабні експериментальні дослідження, насамперед у сфері управління природними ресурсами, її праця має значно ширше застосування - вирішення проблем із виробництва "суспільних благ”, проблем, з якими завжди зіштовхувалася “лібертарна” ( з лат. libertas свобода) думка. 


\section{Список використаних джерел}

1. Элинор Остром. Нобелевская премия по экономике 2009 (за исследования в области экономической организации) [Электронный ресурс]. - Режим доступа : http://nobeliat. ru/laureat.php?id=828.

2. Остром Э. Управляя общим: Эволюция институтов коллективной деятельности / Элинор Остром ; пер. с англ. - М. : ИРИСЭН, Мысль, 2010. - 447 c. (Серия “Экономика").

3. Hardin, G. 1968 Tragedy of the Commons. Science 162 : 1243-1248.

4. Olson, M. 1965. The Logic of Collective Action. Public Goods and the Theory of Groups. Cambridge, Mass. : Harvard University Press.

5. Matthews, R., and J. Phyne. 1988. Regulating the Newfoundland Inshore Fishery. Traditional Values versus State Control in the Regulation of a Common Property Resource. Journal of Canadian Studies 23:158-176.

6. Ophuls, W. 1973. Leviathan or Oblivion. In Toward a Steady State Economy, ed. H. E. Daly, pp. 215-230. San Francisco: Freeman.

7. Heilbroner. R. L. 1974. An Inquiry Into the Human Prospect. New York: Norton.

8. Ehrenfield, D. W. 1972. Conserving Life on Earth. Oxford University Press.

9. Carruthers, I., and R. Stoner. 1981. Economic Aspects and Policy Issues in Groundwater Development. World Bank staff working paper No. 496, Washington, D.C.

10. Demsetz, H. 1967. Toward a Theory of Property Rights. American Economic Review 62:347-359.

11. Johnson, O. E. G. 1972. Economic Analysis, the Legal Framework and Land Tenure Systems, Journal of Law and Economics 15:259-276.

12. Welch, W. P. 1983. The Political Feasibility of Full Ownership Property Rights: The Cases of Pollution and Fisheries. Policy Sciences 16:165-180.

13. Clark, C. W. 1980. Restricted Access to Common-Property Fishery Resources: A Game-Theoretic Analysis. In Dynamic Optimization and Mathematical Economics, ed. P. T. Liu, pp. 117-132. New York: Plenum Press.

\section{References}

1. Elinor Ostrom. Nobelevskaia premiia po ekonomike 2009 (za issledovaniia v oblasti ekonomicheskoi organyzatsii) [The Nobel Prize in Economics in 2009 (for the research in the field of economic organization), from $h$ ttp://nobeliat.ru/laureat.php?id=828 [in Russian].

2. Ostrom Э. Upravliaia obshchim: Evoliutsyia institutov kollektyvnoi deiatelnosty [Governing the Commons: The Evolution of Institutions for Collective Action]. Moscow: Mysl', 2010, 447 p. [in Russian].

3. Hardin, G. (1968). Tragedy of the Commons. Science 162, 1243-1248 [in English].

4. Olson, M. (1965). The Logic of Collective Action. Public Goods and the Theory of Groups. Cambridge, Mass: Harvard University Press [in English].

5. Matthews, R., Phyne J. (1988). Regulating the Newfoundland Inshore Fishery. Traditional Values versus State Control in the Regulation of a Common Property Resource. Journal of Canadian Studies, 23, 158-176 [in English]. 
6. Ophuls, W. (1973). Leviathan or Oblivion. In Toward a Steady State Economy, ed. H. E. Daly, San Francisco: Freeman, pp. 215-230 in Ennglish].

7. Heilbroner. R. L. (1974). An Inquiry Into the Human Prospect. New York: Norton [in English].

8. Ehrenfield, D. W. (1972). Conserving Life on Earth. Oxford University Press [in English].

9. Carruthers, I., Stoner, R. (1981). Economic Aspects and Policy Issues in Groundwater Development. World Bank staff working paper, No.496, Washington, D.C. [in English].

10. Demsetz, H. (1967). Toward a Theory of Property Rights. American Economic Review, 62, 347-359 [in Engliish].

11. Johnson, O. E. G. (1972). Economic Analysis, the Legal Framework and Land Tenure Systems, Journal of Law and Economics, 15, 259-276 [in English].

12. Welch, W. P. (1983). The Political Feasibility of Full Ownership Property Rights: The Cases of Pollution and Fisheries. Policy Sciences, 16, 165-180 [in English].

13. Clark, C. W. (1980). Restricted Access to Common-Property Fishery Resources: A Game-Theoretic Analysis. In Dynamic Optimization and Mathematical Economics, ed. P. T. Liu, New York: Plenum Press, pp. 117-132 [in English].

Редакція отримала матеріал 16 січня 2017 р. 